\title{
The life and works of Giulio Cesare Casseri (1552-1616), who was the pioneer neuroanatomist
}

\author{
İlhan Bahşi ${ }^{1}$ (D) Saliha Seda Adanir ${ }^{1}$
}

Received: 5 January 2019 / Accepted: 13 January 2019 / Published online: 23 January 2019

(C) Springer-Verlag GmbH Germany, part of Springer Nature 2019

\section{His life}

Giulio Cesare Casseri (latinized as Iulius Casserius) also written as Giulio Casser, Iulius Casserius, Giulio Casserio, and Giulio Casserio of Piacenza was born in Piacenza, Italy, in 1552. Therefore, the nickname is known as Piacentino (Placentinus) [1]. Casseri, the son of a very poor family, served as a servant of some students. He worked as a servant of a successful surgeon and anatomist, Girolamo Fabrici d'Acquapendente (Fabricius, 1533-1619) and he undertook the tasks of carrying and cleaning cadaver for dissection. After these, he worked as a student and then as a teacher. It is not known when Casseri matriculated in the School of Medicine of the Universita Artista. It is thought to had graduated from medical school, probably at the age of $28[1,2]$. After his graduation, he started working as a doctor and surgeon in Padua and continued to work for Fabricus. He also taught anatomy to students at Artista University [1-3].

Casseri's growing reputation as a surgeon and anatomist allowed him to replace Fabricus as a member of the board of examiners by obtaining a surgery license [2, 3]. In later years, some conflicts and disputes arose between his and his former mentor, Fabricus [1-3].

Casseri refused to teach many times in the public theater he lectured and held his dissections in his own home theater. In January 1616, he began the three-week anatomy course, which, following the recommendations of the academic authorities, he presented, for the first and only time, in that public

İlhan Bahși

dr.ilhanbahsi@gmail.com

Saliha Seda Adanir

seda.adnr93@gmail.com

1 Department of Anatomy, Faculty of Medicine, Gaziantep University, TR-27310 Gaziantep, Turkey theater [1]. Casseri, after this course on March 8 1616, died as a result of the disease [3].

\section{His books}

Casseri wrote three anatomical books [1, 3]. His first two books are De vocis auditusque organis Historia anatomica

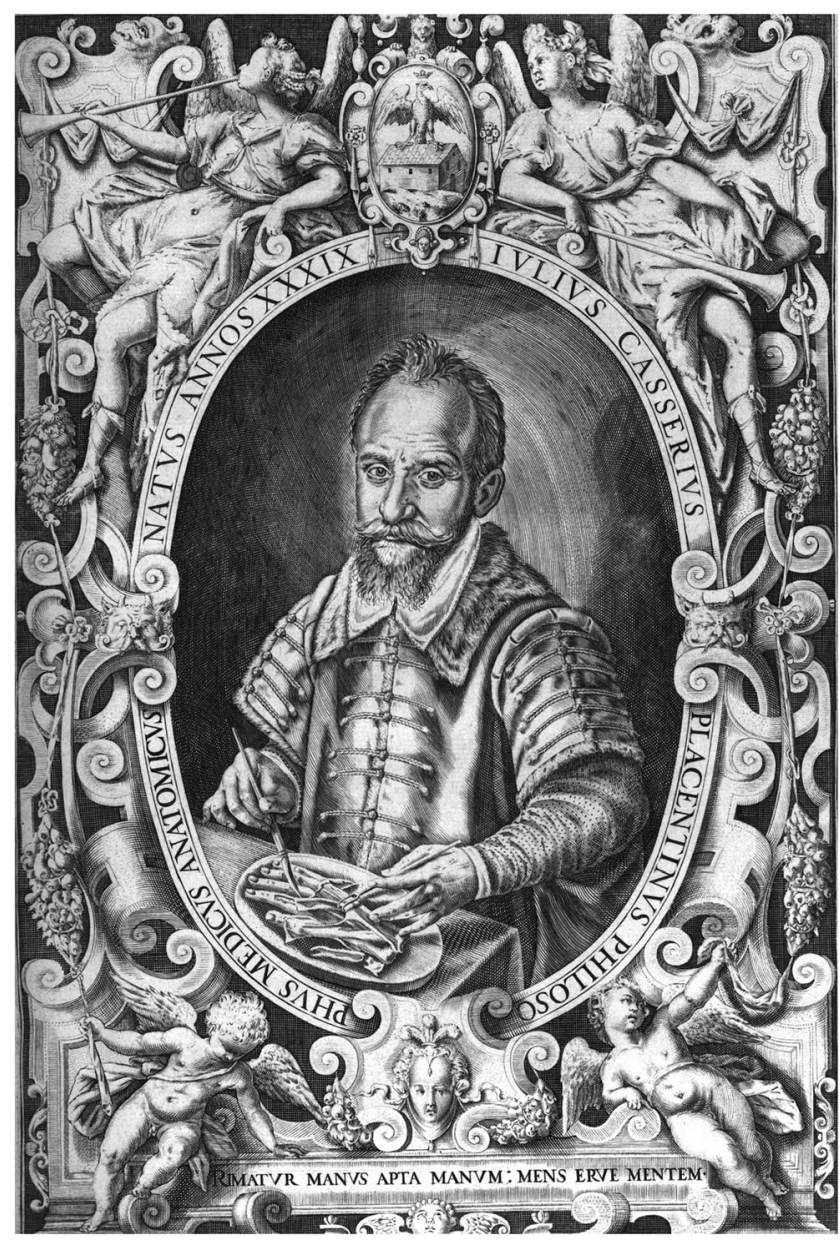

Fig. 1 Giulio Cesare Casseri 
(Ferrariae, 1600-1601) and Pentaestheseion, hoc est De quinque sensibus liber, organorum fabricam variis iconibus fideliter aere incisis illustratam, nec non actionem et usum, discursu anatomico \& philosophico accurate explicata continens (Venetiis, 1609) edited by himself.

His first book, De vocis auditusque organis Historia anatomica, was reprinted in 1607 in Venice. The first page of the book depicts the state of Casseri while dissecting a human hand (Fig. 1). There are many drawings of both human and animal dissections in the book. This book focused comparative anatomy on the auditory and vocal organs.

The second book, Pentaestheseion, has many editions. The sensory organs (touch, taste, smell, hearing, sight) are discussed in this book. There are many drawings such as head bones, ear muscles, inner ear, eyeball, and eye muscles belonging to both human and animal in this book. This book contributed to the comparative anatomy the ear and the vocal organs.

The third book, Iulii Casseri Placentini Tabulae Anatomicae LXXIIX, omnes novae nec ante hac visae. (Venetiis, 1627), was published by Daniel Rindfleisch (latinized Bucretius) 11 years after his death. There are many famous figures drawn by painters and engravers in the book $[1,3]$. In these drawings, many anatomical structures are shown both accurately and clearly and in an artistic way (Figs. 2, 3 and cover).

Bender et al. [2] stated that Christopher Wren and Thomas Willis had fully described and accurately illustrated the anatomy and physiology of circle of Willis. In addition, they stated that it must be recognized, however, that Willis and Wren were not the first to fully depict the circle of Willis, and that this accomplishment should be credited to Casseri.
Fig. 2 Some illustrations in Iulii Casseri Placentini Tabulae Anatomicae LXXIIX, omnes novae nec ante hac visae
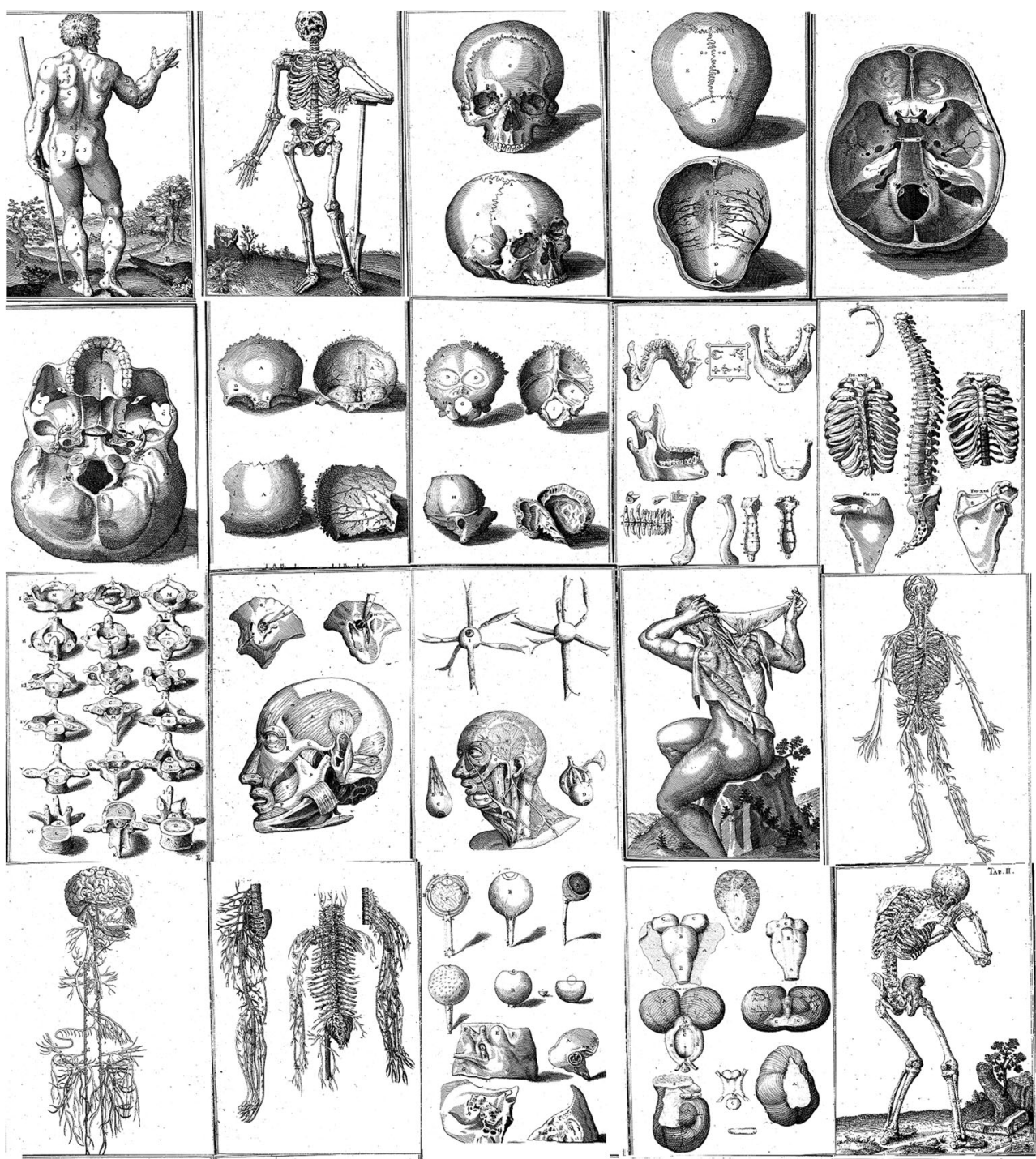
Fig. 3 and cover Brain illustrations in Iulii Casseri Placentini Tabulae Anatomicae LXXIIX, omnes novae nec ante hac visae
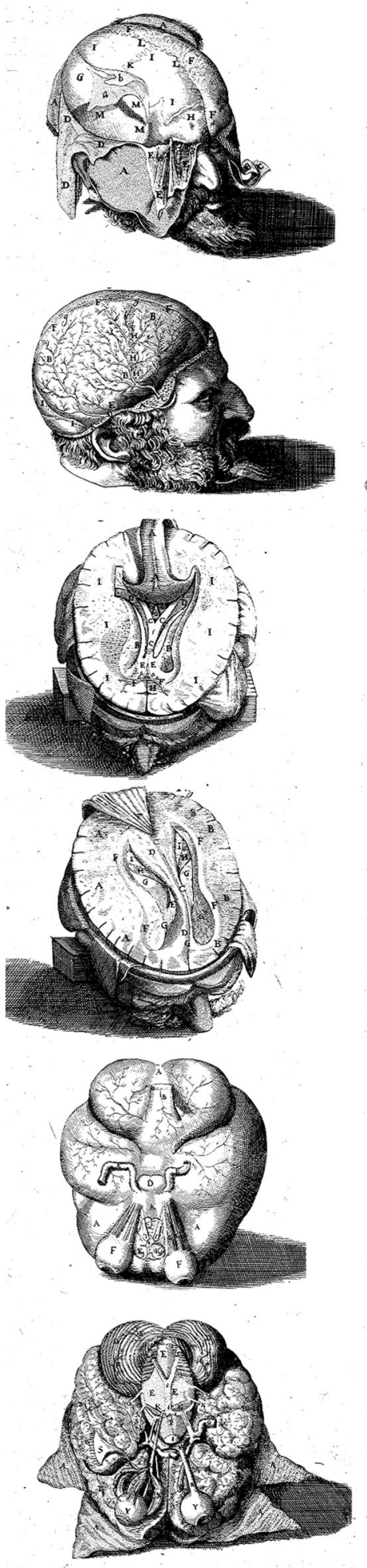
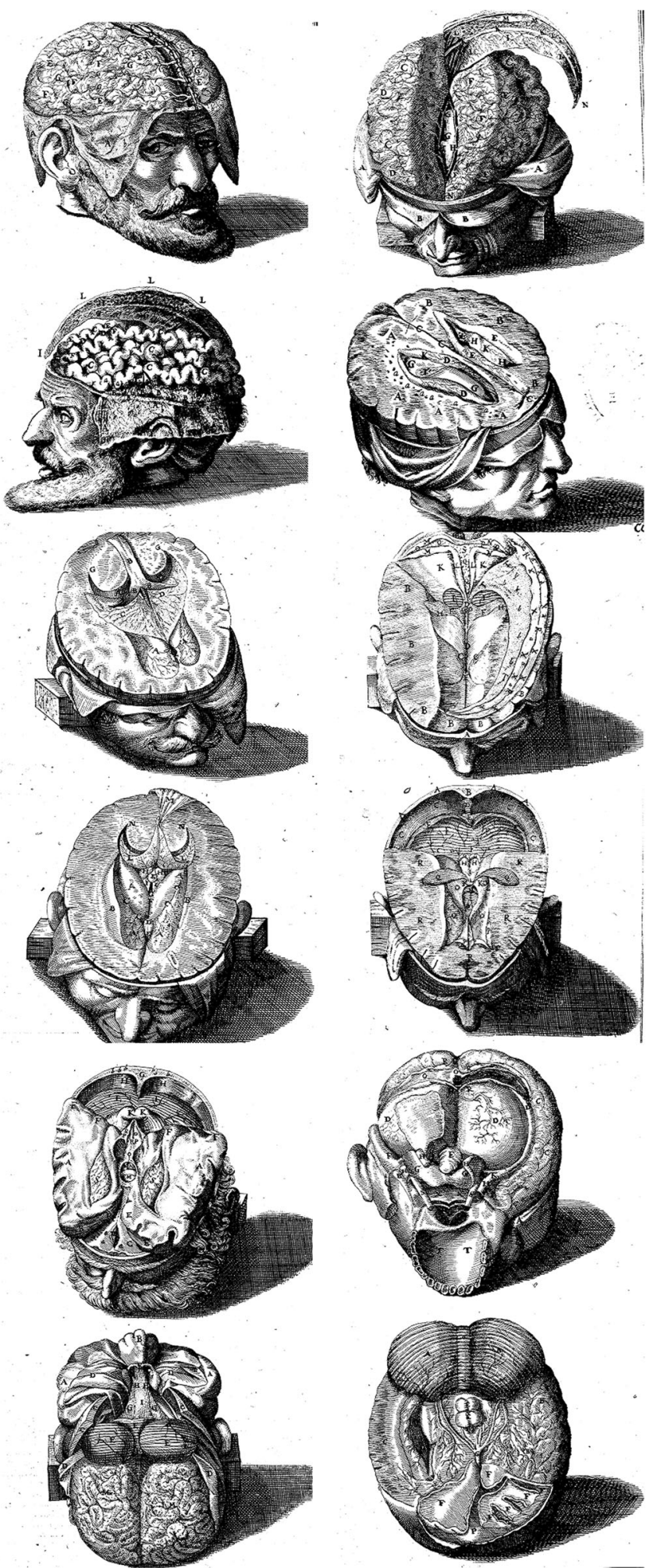

\section{Related eponyms}

Casseri's name is used as an eponym in many anatomical structures [4-6]

Antrum Cesserii: Maxillary sinus

Casser fontanel: Mastoid fontanel

Casserio's nerve, perforans Casserii: Musculocutaneous nerve

Casser perforated muscle, Casserio's muscle: Coracobrachialis muscle 


\section{Conclusion}

In spite of the difficult conditions, Casseri defined many neuroanatomical structures and he compared these structures with the animals. Therefore, his contribution to neuroanatomy cannot be underestimated. For these reasons, he should be appreciated.

\section{Compliance with ethical standards}

\section{Conflict of interest None.}

Publisher's Note Springer Nature remains neutral with regard to jurisdictional claims in published maps and institutional affiliations.

\section{References}

1. Riva A, Orrù B, Pirino A, Riva FT (2001) Iulius Casserius (15521616): the self-made anatomist of Padua's golden age. Anat Rec 265: $168-175$

2. Bender M, Olivi A, Tamargo RJ (2013) Iulius casserius and the first anatomically correct depiction of the circulus arteriosus cerebri (of Willis). World Neurosurg 79:791-797

3. Wysocki M, Saganiak K, Zwinczewska H, Roy J, Tomaszewski KA, Walocha JA (2016) Iulius Casserius: revolutionary anatomist, teacher and pioneer of the sixteenth and seventeenth century. Anat Sci Int 91:217-225

4. Lund V (2002) The evolution of surgery on the maxillary sinus for chronic rhinosinusitis. Laryngoscope 112:415-419

5. Casser fontanel. https://medical-dictionary.thefreedictionary.com/ Casser+fontanel. Accessed 05.01.2019

6. Bell J, Bell C (1834) The anatomy and physiology of the human body Vol II. Collins and Company, New York 